\title{
SERUM EPINEPHRINE AND NOREPINEPHRINE DURING VALVE REPLACEMENT AND AORTA-CORONARY BYPASS
}

\author{
Kanteeraya Balasaraswathl, Silas N. Glisson, Adel A. El-Etr and Roque Pifarre
}

in 1962 Replogle and colleagues' described a significant progressive increase in circulating catecholamine concentration during cardiopulmonary bypass. Lillehei ${ }^{2}$ suggested later that such increases in circulating catecholamines could be responsible for the irreversible shock-like state and low cardiac output syndrome seen occasionally in patients during the post-bypass period. Studies of Vasko, et al. ${ }^{3}$ and Overy, et al. ${ }^{4}$ demonstrated in dogs that intravenous morphine causes a positive cardiac inotropic effect which was thought to be mediated by endogenous catecholamine release. Lowenstein and coworkers ${ }^{5}$ have shown that morphine $1 \mathrm{mg} / \mathrm{kg}$ increases cardiac output in patients with aortic valve disease. Stanley and co-workers ${ }^{6.7}$ measured urinary norepinephrine after morphine 1 to $3 \mathrm{mg} / \mathrm{kg}$ in patients undergoing aorta-coronary bypass and also during valve surgery and found that norepinephrine excretion was increased. Recently, in this laboratory Tan and co-workers ${ }^{8}$ measured catecholamine levels in serum after morphine and enflurane in relation to blood pressure during aorta-coronary bypass surgery and reported significant increases in catecholamines during cardiopulmonary bypass. A single study by Hine and co-workers ${ }^{9}$ reported no significant increase in serum and urinary catecholamines during cardiopulmonary by pass.

The present study was undertaken to measure and to compare serum levels of epinephrine and norepinephrine in patients undergoing valve replacement operations with serum catecholamine levels of aorta-coronary bypass patients to determine whether the different cardiopathies of these two patient types influences their catecholanine response to anaesthesia and operation. We had a particular interest in patients with valvular disease because Yoshida ${ }^{10}$ previously

Kanteerava Balasaraswathi, M.D., Clinical Instructor, Department of Anesthesiology. Silas N. Glisson, $\mathrm{Ph}$.D., Assistant Professor, Department of Anesthesiology. Adel A. E!-Err, M.D., Professor and Chairman, Department of Anesthesiology. Roque Pifarre, M.D., Clinical Professor, Department of Surgery.

Loyola University Stritch School of Medicine, 2160 South First Avenue, Maywood, Illinois.

Canad. Anaesth. Soc. J., vol. 25, no. 3, May 1978 reported finding elevated pre-operative urinary catecholamine levels in such patients.

\section{Patients AND Methods}

Twenty-five adult patients were selected for the study, eight individuals having aortic or mitral valve replacement (Group $A$ ) and seventeen individuals having aorta-coronary bypass (Group B). All the patients were premedicated with morphine $(5-10 \mathrm{mg}$ ) and diazepam (5-10 $\mathrm{mg}$ ) one hour before the operation. Two intravenous catheters were inserted in peripheral veins after the patients arrived in the operating room. The radial artery was cannulated percutaneously with 20FG Teflon indwelling catheter and blood pressure was displayed on an oscilloscope. A central venous cannula was inserted through the internal jugular vein, and central venous piessure was measured at varying intervals during the operation. In addition, urine output and oesophageal and tympanic temperatures were monitored.

All patients were pre-oxygenated for five minutes and anaesthesia was induced with incremental doses of thiopentone ( 3 to $4 \mathrm{mg} / \mathrm{kg}$ ). Tracheal intubation was facilitated with pancuronium bromide $(120 \mu \mathrm{g} / \mathrm{kg})$. Anaesthesia was maintained with a mixture of 50:50 nitrous oxide and oxygen and morphine as required, which varied between 1.0 and $1.5 \mathrm{mg} / \mathrm{kg}$. Arterial $\mathrm{PCO}_{2}$ was maintained between 4.66 and $5.32 \mathrm{kPa}$ (35-40 torr) by controlled ventilation.

The extracorporeal system was primed with two litres of lactated Ringer's solution, $50 \mathrm{ml}$ of 50 per cent glucose and $50 \mathrm{mmol}(\mathrm{meq})$ of sodium bicarbonate. Blood samples were taken at frequent intervals to determine the patient's blood gases, haematocrit and electrolytes. Bypass flows were maintained at $40-70 \mathrm{ml} / \mathrm{kg} /$ minute. Mean perfusion pressure was maintained between 6.65 and $10.64 \mathrm{kPa}$ (50 to 80 torr). Patients were cooled to $28^{\circ} \mathrm{C}$.

At the end of bypass all the patients received calcium chloride $(0.5$ to $1.0 \mathrm{gm})$. No other inotropic agents were given to these patients before, during, or after bypass.

Serum epinephrine and norepinephrine levels 
were measured on $20 \mathrm{ml}$ arterial blood samples drawn at the following intervals: (1) before induction; (2) five minutes after intubation; (3) 30 minutes before the cardiopulmonary bypass; (4) two minutes after partial bypass; (5) eight minutes after partial bypass, and; $(6,7) 20$ minutes before and after termination of cardiopulmonary bypass. Arterial blood pressure was recorded at each of the sampling times.

Serum epinephrine and norepinephrine were determined using a modification of the methods of Vendsalu ${ }^{11}$ and Haggendal. ${ }^{12}$ Basically, each $20 \mathrm{ml}$ of heparinized arterial blood was centrifuged at 4,000 RPM in a refrigerated centrifuge. The plasma was removed and the volume recorded; 0.1 volume per cent of $4.0 \mathrm{~N}$ perchloric acid containing EDTA and ascorbic acid was added to the sample to deproteinize the plasma and stabilize the catecholamines. The plasma was refrigerated for 30 minutes and then centrifuged again for 20 minutes. The acidified deproteinized serum containing epinephrine and norepinephrine was then removed.

Purification and isolation of epinephrine and norepinephrine was accomplished using ionexchange column chromatography. ${ }^{13}$

Quantification of epinephrine and norepinephrine was done after converting the amines to their respective fluorophores using the trihydroxy indole technique. ${ }^{13}$ Developed fluorescence was measured at $400 / 505$ and $450 / 505 \mathrm{Nm}$ in a spectrophotofuorometer equipped with an ellipsoidal mirror condensing system. Norepinephrine and epinephrine concentrations were calculated using equations correcting for the small fluorescence crossover for the two amines.

Institutional approval was obtained as well as written consent from the patients included in this study.

\section{RESULTS}

Eight patients of the 25 studied had valve replacement operations. This group of patients had a mean age of 49.88 years (range 31 to 65 years) and included three females and five males. The remaining 17 patients underwent aorta-coronary bypass. The mean age for this group of patients was 51.65 years (range 38 to 68 years); 14 were males and three females.

Comparison of pre-anaesthetic serum catecholamine levels in patients who had valve replacement operations (Group A) and aorta-coronary by pass patients (Group $B$ ) shows a signifcant difference between the two groups. Group A epinephrine and norepinephrine levels were found to be 47 per cent and 33 per cent higher than Group B levels. No difference in mean blood pressure was found between the two groups (Table I).

TABLE I

Pre-Anaesthetic Epinephrine and NOREPINEPHRINE SERUM LEVELS

\begin{tabular}{|c|c|c|}
\hline Mean \pm S.E. & Valve & A.C Bypass \\
\hline $\begin{array}{l}\mathrm{EPI} \mathrm{mcg} / \mathrm{l} \\
\mathrm{NE} \mathrm{mcg} / 1 \\
\mathrm{BP} \mathrm{mmHg}\end{array}$ & $\begin{array}{l}1.73 \pm 0.34 \\
1.29 \pm 0.20 \\
81 \pm 3\end{array}$ & $\begin{array}{l}-*-0.92 \pm 0.17 \\
-*-0.86 \pm 0.06 \\
-n s-90 \pm 3\end{array}$ \\
\hline
\end{tabular}

$* \mathrm{P}<0.05$.

\section{Valve Replacement}

As shown in Table II and Figure 1, a 48 per cent increase in serum epinephrine occurred following intubation (period 2) in patients having valve replacement operations $(p<0.05)$. Mean blood pressure and norepinephrine levels remained unchanged. In period 3, before cardiopulmonary bypass, the level of serum epinephrine returned

TABLE II

Valve Replacement

(mean \pm s.e. $(n=8)$ )

\begin{tabular}{cccc}
\hline \hline $\begin{array}{c}\text { Sample } \\
\text { periods }\end{array}$ & $\begin{array}{c}\text { Blood pressure } \\
\mathrm{mm} \mathrm{Hg}\end{array}$ & $\begin{array}{c}\text { Epinephrine } \\
\text { mcg/l serum }\end{array}$ & $\begin{array}{c}\text { Norepinephrine } \\
\text { mcg/l serum }\end{array}$ \\
\hline 1 & $81 \pm 3$ & $1.73 \pm 0.34$ & $1.29 \pm 0.20$ \\
2 & $80 \pm 3$ & $2.56 \pm 0.72$ & $1.20 \pm 0.23$ \\
3 & $90 \pm 3$ & $1.65 \pm 0.32$ & $1.56 \pm 0.15$ \\
4 & $62 \pm 5$ & $1.70 \pm 0.21$ & $1.53 \pm 0.16$ \\
5 & $71 \pm 3$ & $2.08 \pm 0.17$ & $1.89 \pm 0.33$ \\
6 & $72 \pm 3$ & $2.19 \pm 0.31$ & $1.78 \pm 0.32$ \\
7 & $73 \pm 3$ & $2.30 \pm 0.49$ & $1.67 \pm 0.31$ \\
\hline
\end{tabular}

(1) Before induction, (2) $5 \mathrm{~min}$ after intubation, (3) $30 \mathrm{~min}$ before the pump, (4) $2 \mathrm{~min}$ after partial bypass, $(5) 8 \mathrm{~min}$ after partial bypass, $(6,7) 20$ min before termination and after termination of cardiopulmonary bypass. 


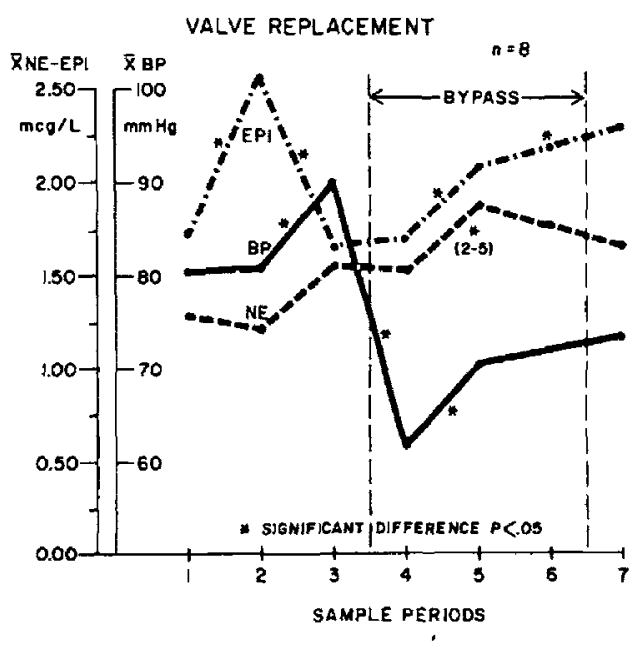

FIGURE 1. Asterisk indicates significance between adjoining sample periods as determined by paired $t$ analysis. Sample periods include: (1) Before induction, (2) minutes after intubation, (3) 30 minutes before the pump, (4) and (5) two and eight minutes after partial bypass, (6) and (7) 20 minutes before termination and after termination of cardiopulmonary bypass.

to the pre-anaesthetic level, while mean blood pressure increased from 10.64 to $11.97 \mathrm{kPa}$ ( 80 to $90 \mathrm{~mm} \mathrm{Hg}$ ). Upon initiation of cardiopulmonary bypass a significant $(p<0.001)$ fall in mean blood pressure was recorded. Within eight minutes (period 5), both serum epinephrine and norepinephrine levels increased ( $p<0.05$ ), as did blood pressure. Twenty minutes before termination of cardiopulmonary bypass (period 6), a further elevation in serum epinephrine and mean blood pressure was observed. Serum norepinephrine levels began a decline towards the period 1 pre-anaesthetic level.

Importantly, post-cardiopulmonary bypass mean blood pressure remained below the preanaesthetic level of $10.77 \mathrm{kPa}(81 \mathrm{~mm} \mathrm{Hg})$ and serum epinephrine levels continued to increase. Serum norepinephrine approached, but was still above pre-anaesthetic levels (Figure 1).

\section{Aorta-coronary Bypass}

Mean blood pressure, serum epinephrine and noreprinephrine levels remained unchanged until period 3 , before cardiopulmonary bypass, when a 20 per cent increase in serum epinephrine and norepinephrine was observed (Table III, Figure 2). Initiation of cardiopulmonary bypass (period 4) was associated with a significant $(\mathrm{p}<0.001)$ fall in mean blood pressure from 12.24 to $8.78 \mathrm{kPa}$ (92 to $66 \mathrm{~mm} \mathrm{Hg}$ ), a response also observed in the valve replacement patients. At this time (period 4), serum epinephrine and norepinephrine levels were increased. As cardiopulmonary bypass continued (periods 5 and 6), parallel increases in

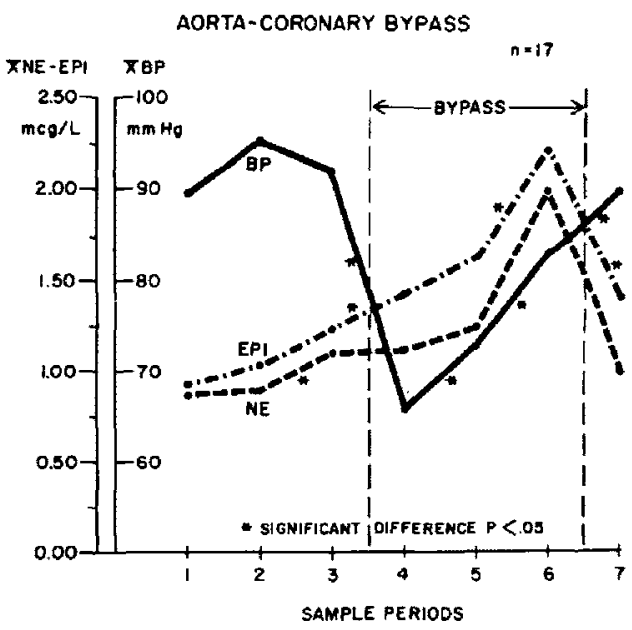

FIGURE 2. Asterisk indicates significance between adjoining sample periods as determined by paired t analysis. For sample period times $\mathrm{cf}$. Figure i.

TABLE III

AORTA-CoRonary BXpass (mean \pm s.e. $(n=17)$

\begin{tabular}{|c|c|c|c|}
\hline $\begin{array}{l}\text { Sample } \\
\text { periods }\end{array}$ & $\begin{array}{c}\text { Blood pressure } \\
\mathrm{mm} \mathrm{Hg}\end{array}$ & $\begin{array}{l}\text { Epinephrine } \\
\text { mcg/l serum }\end{array}$ & $\begin{array}{l}\text { Norepinephrine } \\
\text { mcg/l serum }\end{array}$ \\
\hline $\begin{array}{l}1 \\
2 \\
3 \\
4 \\
5 \\
6 \\
7\end{array}$ & $\begin{array}{l}90 \pm 3 \\
95 \pm 4 \\
92 \pm 4 \\
66 \pm 4 \\
73 \pm 4 \\
83 \pm 4 \\
90 \pm 2\end{array}$ & $\begin{array}{l}0.92 \pm 0.17 \\
1.03 \pm 0.17 \\
1.23 \pm 0.11 \\
1.42 \pm 0.13 \\
1.63 \pm 0.14 \\
2.22 \pm 0.73 \\
1.40 \pm 0.20\end{array}$ & $\begin{array}{l}0.86 \pm 0.06 \\
0.91 \pm 0.11 \\
1.10 \pm 0.13 \\
1.11 \pm 0.10 \\
1.24 \pm 0.17 \\
2.01 \pm 0.74 \\
0.99 \pm 0.20\end{array}$ \\
\hline
\end{tabular}

For sample period times cf. Table II. 
serum epinephrine, norepinephrine and mean blood pressure were recorded $(p<0.05)$. After cardiopulmonary bypass, mean blood pressure and serum epinephrine and norepinephrine returned to the period 1 pre-anaesthetic levels.

\section{Discussion}

This study has demonstrated several important differences in the serum catecholamine response of patients with valvular diseases and patients with coronary artery disease during their operative course

Pre-operatively, patients with valve disease had significantly higher epinephrine and norepinephrine levels compared to the coronary artery patients, although mean blood pressures were not different. Similar findings were reported in an earlier study. Yoshida ${ }^{10}$ found chronically elevated urinary catecholamines in patients with valvular disease. In these patients, who typically have low cardiac output, the increased catecholamine excretion was thought to reflect compensatory mechanisms activated to improve their cardiac function.

During operation the valve patients appear more labile than the coronary bypass patients with respect to circulating catecholamine levels. Previous studies of Hasbrouck ${ }^{14}$ and Replogle, et al.' demonstrated increased circulating epinephrine following morphine; and Liu, et al. ${ }^{15}$ recently reported increased urinary norepinephrine after fentanyl. In the present study, increases in serum epinephrine and norepinephrine occurred after morphine in both groups; however, in the valve group epinephrine levels increased dramatically following morphine. This response, coupled with the finding of elevated preoperative catecholamine levels, suggests that the patient with valvular disease may be more sensitive to pre-operative and intra-operative stimuli, drugs, shock, pain and anxiety than other types of patients. ${ }^{16}$

Both the aorta-coronaty bypass and the valve patients demonstrated an increase in serum epinephrine and norepinephrine following initiation of the cardiopulmonary bypass. This response has been shown previously by several investigators using a variety of anaesthetic agents and patient types. $1,6.8$

The increase in serum catecholamines during cardiopulmonary bypass appears related to the adequacy of perfusion. During the bypass period, the mean blood pressure in both groups of pa- tients was considerably below the level during the pre-bypass period. The increase observed in serum catecholamines probably represents a sympatho-adrenal response to the hypotension. This is supported by the finding in the aortacoronary bypass group that the serum catecholamine elevation ceases when mean blood pressure returns to the pre-hypotensive level.

During the latter part of cardiopulmonary bypass an important difference can be seen between the valve group and the aorta-coronary bypass group. Those patients with valve disease do not recover from the hypotensive episode as rapidly as do the aorta-coronary bypass patients. In fact, after cardiopulmonary bypass the mean blood pressure of the valve group was still significantly below pre-bypass levels. The continuing elevation of serum epinephrine into the period after bypass indicates on-going compensatory processes to recover the blood pressure. This difference in aorta-coronary bypass and valve patient blood pressure and serum catecholamine response after bypass may be due to decreased post-bypass cardiac output reported to occur following valve replacement operations. ${ }^{6}$ Unfortunately we were unable to perform cardiac output measurements in this study and therefore can only suggest decreased cardiac output as the reason for the differences.

A question arises as to whether an elevated catecholamine response during cardiopulmonary bypass is advantageous or disadvantageous. Since catecholamines increase myocardial work and oxygen demand, elevated catecholamines may be considered detrimental to patients with coronary artery disease. On the other hand, as suggested by Stanley (personal communication), increased catecholamine levels during cardiopulmonary bypass in patients with valvular disease may promote improved myocardial inotropy at the end of bypass and enable a smoother and more rapid conclusion of extracorporeal support. Further studies are required to determine the value or detriment of elevated catecholamines during different types of cardiac surgery.

In conclusion, this study has shown that patients with valvular heart disease differ from those with coronary artery disease in their catecholamine response to anaesthesia and surgery. Valvular patients have also been shown to differ in oxygen requirements and in pulmonary and cardiac dynamics, ${ }^{17}$ all of which emphasize the point that anaesthetic considerations are not the same in valvular and coronary artery diseased patients. 


\section{SUMMARY}

A comparison of the levels of serum epinephrine, norepinephrine and blood pressure was made in 25 patients undergoing aorta-coronary bypass or valve replacement who were anaesthetized with a nitrous oxide-narcotic technique. Serum epinephrine and norepinephrine were measured in arterial samples drawn pre-induction, post-induction, before cardiopulmonary bypass, two and eight minutes after initiation of cardiopulmonary bypass, 20 minutes before termination and after termination of cardiopulmonary bypass. In both patient groups significant increases in epinephrine and norepinephrine occurred before cardiopulmonary bypass, with accompanying increase of blood pressure in the valve replacement patients. During cardiopulmonary bypass an initial hypotensive response $(\mathrm{p}<0.001)$ was recorded, followed by a significant increase in blood pressure and epinephrine in both groups. After cardiopulmonary bypass, aorta-coronary bypass patients had epinephrine, norepinephrine and blood pressure equal to levels before cardiopulmonary bypass. In contrast, serum epinephrine continued to rise in the valve replacement patients, with a gradual recovery of blood pressure to pre-bypass levels. These findings demonstrate significant differences in blood pressure and catecholamine response in patients with valvular disease from patients with coronary artery disease.

\section{RÉSUMÉ}

Les taux sériques d'épinéphrine et de norépinéphrine, ainsi que la pression artérielle, ont été comparés chez 25 malades opérés à cœur-ouvert pour pontage aorto-coronarien ou pour remplacement valvulaire, sous protoxyded'azote et narcotique. On a fait les mesures d'épinéphrine et de norépinéphrine dans le sang artériel avant l'induction de l'anesthésie, après l'induction, avant le début de la circulation extracorporelle, deux et cinq minutes après le début de la C.E.C., 20 minutes avant sa fin, et enfin après la C.E.C.

L'on a observé avant la C.E.C. une élévation significative de l'épinéphrine et de la norépinéphrine chez les deux groupes de patients, avec élévation de la pression artérielle chez les valvulaires.

Durant la C.E.C., on a observé une élévation significative de la pression artérielle et de l'épinéphrine chez les malades des deux groupes après un épisode initial d'hypotension.
Après la C.E.C., les taux d'épinéphrine et de norépinéphrine et la pression artérielle des malades opérés pour pontage aortocoronarien étaient comparables aux taux précédant la C.E.C. Par contre, les taux d'épinéphrine continuaient d'augmenter chez les valvulaires avec retour graduel de la pression artérielle aux niveaux observés avant la pompe.

Ces résultats illustrent l'existence d'une différence significative de pression artérielle et de taux de catécholamines chez les valvulaires, en comparaison avec les malades présentant une pathologie coronarienne.

\section{ACKNOWLEDGEMENT}

The authors gratefully acknowledge the assistance of Dr. K.B. Ramakrishnaiah and Joe Miculinich.

\section{REFERENCES}

1. Replogle, R., Levy, M., Dewall, R.A. \& LilLEHIE, R.C. Catecholamine and serotonin re sponse to cardiopulmonary bypass. J. Thoracic Cardiov. Surg. 44: 638-648 (1962).

2. Lillehie, R.C., Longerbeam, J.D., Bloch, J.H., \& MANAX, W.G. The nature of irreversible shock. Ann. Surg. 160:682-710 (1964).

3. VAsKo, J.S., HeNney, R.P., BRAWley, R.K., Oldham, H.N., \& Morrow, A.G. Effects of morphine on ventricular function and myocardial contractile force. Amer. J. Physiol. 210: 329-334 (1966).

4. Overy, H.R., Pfister, R., \& Chidsey, C.A Studies on the renal excretion of norepinephrine. $J$. Clin. Invest. 46: 482-489 (1967).

5. Lowenstein, E., Hallowell, P.. \& Levine, F.H. Cardiovascular response to large doses of intravenous morphine in man. N. England J. Med. 281: 1389- 1393 (1969)

6. Stanley, H., ISERn-Amaral, J., \& Lathrop, G. Urine norepinephrine excretion in patients undergoing mitral or aortic valve replacement with morphine anesthesia. Anesthesia and Analgesia 54: 509-517 (1975).

7. StANLEY, T.H., ISERN-AMARAl, J., \& LATHROP, G.D. The effects of morphine and halothane anesthesia on urine norepinephrine during and after coronary artery surgery. Canad. Anaesthesia Soc. J. 22(4): 478-485 (1975).

8. TAN, C., Gl.isson, S.N., El-ETR, A.C., \& YOUNES, S.H. Adrenal response to cardiovascular surgery using morphine and enflurane anesthesia. Excepta Medical International Congress, Series No. 387: 128-129 (1976).

9. Hine, I.P., WoOd, W., Mainwaring-Burton, R.W., Jutler, J., lrving, H.J., \& BOOKer, B. The adrenergic response to surgery involving cardiopulmonary bypass, as measured by plasma and urinary catecholamine concentrations. British Anaesth. 48: 355 (1976) 
10. YoSHIDA, Y. Studies on the pathologic physiology of pulmonary hypertension in mitral valve disease 1. The role of the sympathetic nervous system on the increment of pulmonary vascular resistance. Jap. Circ. J. 33: 359-376 (1969).

11. Vendsalu, A. Studies on adrenalin and no:adrenalin in human plasma. Acta Physio. Scand. 49 (173) (1960).

12. HAGGENDAL, J. An improved method for fluorimetic determination of small amounts of adrenalin and noradrenalin in plasma and tissues. Acta Physio. Scand. 59: 242-254 (1963).

13. Glisson, S.N., Karczmar, A.G., \& Barnes, C. Cholinergic effects on adrenergic neuro transmitters in rabbit brain parts. Neuropharm. 1/(4): 465-577 (1972).
14. Hasbrouck, J.D. Morphine anesthesia for openheart surgery. Ann. of Thorac. Surg. 10:364-369 (1970)

15. LIU, W-S, BidWal, A.V., LUnN, J.K., \& STaNLEY, T.H. Urine catecholamine excretion after large doses of fentanyl, fentanyl and diazepam and fentanyl, diazepam and pancuronium. Canad. Anaesth. Soc. J, 24:371-379 (1977).

16. Moore, F.D. Endocrine changes after anesthesia, surgery and unanesthetized trauma in man. Rec. Progr. Hormone Res. 13:511-582 (1957).

17. Bedford, R.F. \& Wollman, H. Post-operative respiratory effects of morphine and halothane anesthesia: a study in patients undergoing cardiac surgery. Anesthesiol. 43: 1-9(1975). 